\title{
The Utilization of Business-Track Diplomacy: The Hyundai Group's Mt. Kumgang Tourism under the Kim Dae-Jung Government
}

\author{
JEONG-YONG KIM \\ Nortbeast Asia Policy lnstitute
}

\begin{abstract}
This article presents the model of 'business-track diplomacy' to test a state's utilization of economic engagement strategy as security policy. The model provides ways to think atound security issues and alternative security options that go beyond the traditional military containment approach to security in international telations. As a case study, the article investigates Hyundai Group's Mountain Kumgang turrism with North Korea. In this case study, it demonserates that not only the Kim Dae-Jung government's strong policy-making will of business-track diplomacy towards North Korea but also the Hyundai Group's business will and vulnerability of the North Korean economy played important roles in realizing the tour project and thus, enhanced inter-Korean economic cooperation.
\end{abstract}

Keynords: business-track diplomacy, inter-Korean economics, Hyundaj group, Mt. Kungang tourism, economic security policy, chaebol, sunshine policy

Direct all correspondence to Dr. Jeong-Yong Kim, Northeast Asia Policy Institute, 400-103, Jeong-Suk Building B-703. Shirhung-dong 3ya, 7-241 Joonggu, Incheon cicy, Korea; Tel: 82-32-887-1915; Fax: 82-32-887-1916; E-mail: warwick@ (ânmail.net 


\section{ECONOMIC ENGAGEMENT AS AN ALTERNATIVE SECURITY APPROACH}

$\mathrm{T}$ he end of the Cold War, followed by the German reunification, have caused policy-makers in South Korea to consider approaches for a breakaway from South Korea's military and containment sccurity policy rowards North Korea. The nced for new security approaches by South Korea has also been enthanced by the fact that North Korea's economy has almost come to a collapse, at least from the perspective of the outsidic world. Since the 1990 s, there has been possibility that North Korea will implode or explode due to economic hardship. Thus, the question of how South Korea can best deal with the post-Cold War security threat posed by North Korea has been raised. One of the new approaches to ease tensions on the Korean Peninsula and lower the security threat to the region is to engage North Korea economically.

Economic engagement, as one of the alternatives for tackling international insecurity, could contribute to establishing stability and peace around the world. This means chat the range of appropriate means in the service of security objectives can be extended from mainly military measures towards comprehensive methods that combine cconomic mcasures with military power. Fconomic interactions and interdependence among statcs has in itself a protential for heing a tool in the service of security objectives. For instance, the L.S. President Clinton tried to articulate his foreign policy agenda by offering the concept of "democratic enlargement" with military power after he took office in 1993. He argued that "democracies rarely wage war against each other"("The White House 1994, 3). This was further developed as the national security strategy of "Engagement and Erlargement." The grand security strategy of the L'nited States was about spreading democracy through the promotion of free trade. The importance of economic measures in the Clinton administration's foreign policy is quite different from that of the Reagan and Bush administrations. Economic power not only scrved as the foundation of national security capabilitics but also as the instrument of national security. Friedman (1993, A3) identified the core of the Clinton administration's cnlargcment strategy as "Big Mac I: no two countrics that both have a McDonald's have ever fought war against each orher."

The relationship between economic interdependence and national security has been a crucial subject for debate among different schools in international politics. The idea of economic interdependence has important implications for security issues. It is certainly not a new or difficult notion that two or more units are dependent on one another for economic benefit. However, the question of the connection betwecn cconomic interdependence and national security is not an casy one to answer. Economic intcrdependence is to many pluralists what the balance of power is to realists and what dependency is to many neo-Marxists or globalists.

Dependency theorists and neo-realists are skeptical about economic interdependence 
as a possible mechanism for international peace, and they emphasize the valnerability of dependent states and their exploitation by dominant states. However, plutalists take economic interdependence to be the core of international relations. There are three basic ways in which economic interdependence between scates can help to teduce conflict and promote peace. First, free trade supporters (Oneal and Russett 1997; Polachek 1997) envision a peaceful world evolving frorn economic interdependence and economic interests, in which each state produces the products in which it has a comparative advantage. Such a systen would work the economic benefits for all, but more importantly, it would generate such interdependence that conflict between states would have to be reduced for fear of disnapting important external sources of supply and thus economic growth. Economic interests would force political leaders to seck peace in order to maintain economic prosperity in an interdependent and specialized world.

Second, in the cultural explanation of trade and conflict, functionalists and neo-functionalists point out that collaborations in the non-political and functional sectors provide for a more peaceful world. According to functionalists, involvement in economic eransactions across states will tend to generate common ways of looking at issues and new loyalties in which individuals begin to recognize the interests they share with people in other societies. Ernst Haas" (1964) "spill-over" effect indicates that the development of collaboration in one sector will lead to comparable behavior in other sectors as a result of learning from cooperation. Hence, power-oriented governments can redefine their self-interest and can adopt welfare-oriented actions rather than military-oriented actions. These forms of cooperation lead to international institutions and other economic or social linkages between states that make military measures in conflicts more unacceptable.

Similarly, Keohane and Nye (1977) proposed the idea of complex interdependence, which is a situation in which one state cannot take advantage of another state because an evenly balanced mutual dependence exists between them. Keohane and Nye (1977, 99-112) present three main structures that decrease a country's dependency on another country. First, multiple channels, such as non-governmental activities and tics as well as formal foreign office arrangements, should be established. Second, the agenda of interstate relationships, which consists of multiple issues, should not be arranged in a clear hierarchy. This means that military security does not consistently dominate the agenda. Third, military force should not be used for resolving disagreements. Therefore, economic interdependence is deepened by non-military activities. These activities include economic exchanges that can change another state's behavior and make it act more peacefully through its redefinition of common interests and through domestic pressure from multiple channels and linkages in the interstate system.

Third, some argue that peace can result from democratic practices between states (Gleditsch and Hegre 1997; Oncal and Russett 1997). Coordination and bargaining are so embedded within democratic societal norms that democracies are able to solve disputes peacefully, especially with other democracies. Another explanation is that 
there are so many checks and balances in the democratic decision process that making the decision to fight is difficult. Non-democracies, such as dictatorships, need less justification to go to war. In terms of 'democratic peace,' trade and economic interactions can contribute to the transformation towards democracy: democracics usually are free-markct or mixed economies, which are open to the wotld economy (Russett and Starr 1996, 344-8). Therefore, economic operness and interactions can contribute to the development of a democratic society. However, questions remain about the causal relationships between democracy and international peace. ${ }^{1}$

Following the pluralists' view of economic interdependence, this article investigates the positive aspects of economic interdependence as South Korea's policy to promote its long-term national security objectives, which are peacefully resolve the post-Cold War North Korean security problems, and to seek Korcan reunification. Therefore, the next section will introduce various types of state economic security policies, and it will clarify the notion of an economic security policy that this study seeks to evaluate for the situation in Korea.

\section{TYPES OF ECONOMIC SECURITY POLICY}

If the state is taken as the main player in economic security policy, there are four different types of economic security policies. These policies are defined in terms of state goals and means. The first type of economic security policy is referred to as a policy intended to increase or preserve the wealth and welfare of the citizens. States require ready access to the means necessary for their survival. For instance, South Korea and Japan do not possess sufficient resources, so trade becomes an essential part of their basic economic security policy. Murdock $(1977,69)$ points out that this type of economic security sees the "economic issue as the security issue itself." This type of economic sccurity policy is related to economic cfficiency and the decrease of vulncrability, and it is developed along similar lines as the realist's argument. Knorr (1977) points out that economic vulnerability that stems from interdependence should be regarded as a security problem. The concept of "national coping mechanism" (Murdock 1977, 75-76) can be seen as this type of economic security policy. The mechanism is characterised as either "defensive" or "offensive." The defensive mechanism refers to reducing vulnerability by internal adjustment, such as through domestic monetary control policy and regulations on exports and imports. The offensive mechanism refers to the use of national capability to prevent external actors from exploiting national vulnerability. For instance, this could be done by creating rival trading blocs within a multilateral framework. This type of economic security policy aims to secure the economic well-being of a state through the types of measures discussed above.

\footnotetext{
Accurding so John Rourke (1991, 118-9), dcrnoctary is not always a force for peace. The concentration of execurive power and also public pressure towards war mighe lead a government to wage war. Examples are the United States Johnson administration's intervention in Vietnarn, the Carter adrinisctation's attempted hoscage rescue in Iran, and the Reafan administrations sale of weapons to Iran
} 
The second cype of economic security policy is concerned with instruments of economic power that enable a state to punish another state, thereby affecting the lacter's behavior before and during a political, military, of economic conflict. This type of foreign policy is often called "stick." There are many techniques for using this policy: trade embargo, boycott, freezing assets, aid suspension and so on. Knorr's $(1977,99)$ conception of "coercive economic power," and Baldwin's (1985, 40-42) "negative sanction" point to this type of economic security policy. This type of economic security policy is a short-term and conditional economic pressure through the denial of economic resources to a target state in return for the target state's favorable political or military reactions. However, this type of policy can be unsuscessful. It is arguable that this policy can increase the risk of war, especially if the target state is informed that the opposing state might respond with warfare (Baldwin 1985, 111-4). Other negative results of this policy ate ineffectiveness and immorality. For example, the sanctions used against Iraq after Iraq's invasion of Kuwait in 1990 failed to convince Iraq to withdraw from Kuwait, and they only hurt the Iragi people and contributed to the consolidation of Saddam Hussein's regime. Because of the unpredictability of the tesults, and the unintended effects of these relations, this type of policy is limited in its usefulness.

The third type of economic security policy uses economic means to force other states to change their behavior in the face of potential or actual conflict in political, econornic, or military matters. Also, economic disputes between states and economic hardship in a particular state can generate domestic and international instability, which may promote military conflicts. Thus, the aim of this policy is to preserve a peaceful envitonment and to prevent conflicts between states by offering both economic benefits to the target state in return for its desired behavior and by decreasing the source of conflict in terms of economic problems. The opposite of the "stick," policy is the third type of cconomic security policy, which is often called "carrot." Baldwin's (1985, 40-42) concept of "positive sanction" refers to this type of policy. The usual technique for implementing this policy is through economic aid: i.e., direct grants or favorable loans, development assistance, and investment. Examples of this type of policy include the Marshall plan of the United Stazes after World War II, which supplied capital for the tedevelopment of the European economies. It also provided for the financial and technical assistance of industrialized countries toward Eastern Europe and the former Soviet Union, in an effort to prevent the re-emergence of communism. Also, the construction of a light-warer reactor in North Korea by the Korean Peninsula Energy Development Organization (KEDO) in return for North Korea's abandonment of its nuclear weapons program as a solution for the 1994 North Korean nuclear crisis is also an instance of this type of policy. However, this type of policy is also used like the second type of economic security policy when short-term conflict can be prevented in a peaceful manner, or to prevent future potential international instability.

Finally, the forth type of economic security policy is the establishment of peace 
and cooperation between states through economic and social incerdependence. Economic and social interdependence through trade and other economic activities is the basic means to promote security objectives. The difference between the second and third types of policy is a longer-term commitment. Policy-makers must perceive the long-term impact of economic and social interdependence on peace and stability. Strange's (1997, 31 ) concept of "structural power" also applics where "the range of options open to others will be extended by giving them opportunities without direct pressure they would not otherwise have had." Also, "complex interdependence," which consists of multiple channels and an absence of hierarchy among issues, provides for less use of military force, and it promotes the use of non-violent means to resolve disputes (Keohane and Nye 1977). This type of policy aims to help establish economic and social linkages that arc mutually beneficial to states. Economic interactions between states will increase the "sense of community" (Deutsch 1957, 5) through economic ties and social communication.

As discussed above, the first type of economic security is designed to decrease a state's economic vulnerability by using several mechanisms. However, this is not the type of economic security this thesis focuses on. The second type of economic security policy is to use economic power in order to push target states to behave more favorably towards a state, and it uses economic "sticks." However, this policy often increases the risk of war and it is often used as a pressure in combination with military power. Thus, the first and second types of economic sccutity policies are similar to the realist arguments that see economic interdependence as a possible cause for escalating conflicts.

However, the third and forth types of policy are based on liberalist arguments. In order to explore the positive aspects of economic engagement and interdependence in the case of the inter-Korean security relations in the post-Cold War era, this thesis looks at the third and forth types of economic security policies as South Korea's possible security approaches to its security goals with regard to North Korca. Although the third type of economic security policies make use of the short-term impact of economic measures to affect the target state's behavior in the event of conflict, they can be important as a stepping-stone to economic interdependence in the long run. In the article, the economic interdependence strategy refers to a long-term commitment, and thus, to the promotion of an environment of economic linkages and other social relations in which a target state is less likely to resort to coercive strategies in resolving disagreements.

\section{THE CONCEPT OF BUSINESS-TRACK DIPLOMACY}

South Korea's difficulty in the promotion of inter-Korean economic cooperation is the result of fact that North Korea has tried to avoid direct contacts with the South Korean government because of a fear of absorption by the South. Instead, 
North Korea has made continuous efforts to engage with the United States, Japan, and even South Korea's private sector, especially the business community, for its survival. Thus, certain South Korean political leaders, especially President Kim Dae-Jung and his supporters, began to realize the need for an active role by the private sector to foster inter-Korean economic cooperation.

One of the notable avenues for resolving conflices and making peace based on the important tole of the private sector is expressed in the concept of "business-trackdiplomacy" (Diamond and McDonald 1996). In fact, business-track is one of nine tracks in their model of "multi-track diplomacy."2 They outline nine different tracks, which comprise a system for creating international peace. The nine tracks are government, non-governmental conflict resolution professionals, business, private citizens, research and education, activism, teligion, funding, and the media.

Track three, or business-track diplomacy, is related to the notion of a liberal economic security policy. Peacemaking through commerce operates by enhancing the economic health of peoples and nations, thereby relieving some of the economic pressures of poverty and unsatisfied human needs that can lead to domestic disorder, and possibly conflict. Moreover, it is the exchange mechanism of the system that opens the door to social relationships between states and also between private and public sectors. These interactions, through goods, services, or information, create mutual confidence among states (Diamond and McDonald 1996, 52-56).

Trade is a major vehicle through which global interclependence is actualized, so it can be a doorway to bonds of mutual trust and benefit that strengthen ties between states. Thus, the concept of business-track diplornacy is concemed not only with common economic interests but also to aid social and cultural bonding through continual contacts and the exploration of common interests. It is closely associated with Deutsch's (1957) notion of a "sense of community." He argued that trade and other forms of intercultural exchange would help foster the development of a common identity. This would make resorting to violent forms of conflict resolution increasingly unlikely.

This model was developed as a reaction to the frustration that formal, official, government-to-government interactions between representatives of states were not necessarily effective methods for securing international security, and often resulted in states' use of coercive power to resolve conflicts. Thus, the role of non-state actors in international peace is an important fearure of this system. Diamond and Mcdonald $(1996,2)$ point out the contributions of non-state actors to international peace are "to reduce tension and conflict between groups or nations by improving communication, understanding, and relationships; to decrease tension, anger, or misunderstanding

\footnotetext{
Is has evolved from the concept of "Track Two diplormacy," which focused mainly on the work of non-governmental professionals to help formal negociation between states in the field of conflict resolution. Ttack-two operation is designed to assist official leaders by compensating for the psychological constraints such as rension, anger, fear, or misunderstanding imposed on them and by improving communication, understanding, and relationships among them. Montville $(1987,7)$ described in as "a prosess designed to assist official leaders to resnive or to manage conflict exploring pussible solutions out of public view and without the requirement to formally negoriate or bargain for advantage."
} 
by giving people direct personal experience of one another; and to affect the thinking and actions of governments by addressing the root causes, feelings, and needs which have caused the conflict."

Thereby, non-state actors carrying out their goals are an important premise of busincss-track diplomacy. The business community, such as Multinational Corporations (MNCs), will be the essential forces driving this business-tsack diplomacy for security purposes. As will be discussed later, Hyundai Group's strong interest in pursuing business with North Korea greacly helped to enhance the Kim Dae-Jung government's engagement efforts with North Korea.

However, this does not mean that the government is not an important actor in this model, because it is still where ultimate decisions are made concerning war, peace, and the commitment of national resources. Diamond and Mcdonald (1996) still see government as the most important actor in operating "multi-track diplomacy." They point out the importance of intra-systemic cooperation berween the government and the private sector, and argue that governments are the only part of the multi-track system that can conclude formal agreements and treaties with other nations. As will be discussed later, because there are continuing political and military tensions between the two Koteas even in the post-Cold War ara, the South Korean government's political energy would be necessary to create a favorable environment for the private sectors to engage in business in North Korea.

In fact, private sector diplomacy will not be successful without an alliance with the government. Thus, cooperation between the private sector and states is needed to use business-track diplomacy for meeting security objectives. When the relationships between the private and the public sector are adversarial or undeveloped, the multi-track activity operates with unfulfilled or distorted potential. Therefore, a "natural alliance" between the government and the private sector is the most important requirement for the success of this type of diplomacy (Diamond and McDonald 1996, 156-61).

\section{PREREQUISITES FOR BUSINESS-TRACK DIPLOMACY}

If a statc as a whole is to pursue and actually implement business-track diplomacy towards a target state for its security objectives, it needs to possess two important prerequisites: "economic capability" and "policy-making will." Economic capability refers to the possession of economic resources by either the government or the private sectors to conduct economic activities with target staces in the service of security concerns. Policy-making will refers to the will of the government and private sectors to pursue business-track diplomacy for long-term security purposes. Moreover, because the government and the privare sector may have different interests and motivations for engaging in economic activities with target states, policy-making will require close cooperation between these two sectors. 


\section{ECONOMIC CAPABILITY}

The first prerequisite of business-track diplonacy relates to the economic capability of a state and its private sector. Capability means the possession of economic capacity by actors sufficient to make a target state interact economically with them. Therefore, the question is whether or not a state has the economic power to engage with target states through business activities. In order to engage with a target state, a state, both in its public and private sectors, should possess the essential economic assets that a target state is looking for through its own economic activities.

The first rype of economic capability is indirect economic power. The argument is that a state does not necessarily have to manipulate economic power in the conscious service of nacional policy, but that the scale and extent of its economic linkages, as expressed through international markers, economic regime, and institutions, can be sufficient to shape the environment and the policy options and behavior of other states in the international system. Robert Keohane and Joseph Nye, $(1977,11)$ when elaborating complex interdependence theory, referred to it as the "control over outcornes." Moreover, Nye $(1990,169)$ later drew attention to the idea of "soft power," which he saw as responsible for the maintenance of U.S. hegemony, which is manifested by a dominance over information flows, which in turn the sets norms in the world economy, such as free trade and management practice of TNCs. Thus, states can indirectly derive power and achieve goals as a result of the economic penecration of other states.

The second rype of economic capability refers to the conscious manipulation by a state of economic power resources in order to directly influence the behavior of another state and change it to a course of action that it would not normally take. The desired security effect of direct economic capability is that pusitive sanctions and economic benefits, such as the extension by one state to another of trade and aid privileges, will provide incentives for cooperarion between states. However, negative sanctions and economic costs, such as threats to remove MFN, status or the imposition of economic embargos, will force states into compliance with the interests of other states.

The third type of economic capability is related to a target state's vulnerability. In other words, a target state has to see tangible benefits from economic interaction. Thus, a target state's economic difficulties and also its vulnerability can increase the economic capability of the actors in the other state to utilize business-track diplomacy. Vulnerability could result from economic or security threats caused by international economic interdependence. Conversely, economic self-reliance or independence may increase economic difficulties, and thus expose a potential vulnerability to external factors. North Korea's economic difficulties in the $1990 \mathrm{~s}$ indicate this type of situation. North Korea's lack of adaptability to international trends of economic interdependence and liberalization in the Cold War era actually contributed to its economic insecurity, and this ironically increased its vulnerability to external forces (Smith 1999). 


\section{POLICY-MAKING WILL}

Following the capability for business-track diplomacy, the second prerequisite of this model is policy-making will, which refers to the policy-makers' will for the actual mobilization of the economic capability in the service of security objectivcs. Howcver, the pursuit of economic-based forms of security policy, which are aimed at the long-term establishment of complex linkages and interdependence with a target state, is not easily compared with military security policy. The latter is relatively easy to mobilize, and it can quickly satisfy domestic and international political demands for action. Since the positive effects of business-track diplomacy may only become visible in the long term, it can be assumed that the pursuit of consistent business-track diplonacy would require a high degree of political will and energy by the actors.

As pointed out earlier, the most important actor in this regard is the government. Political will for policy-making that utilizes business-track diplomacy is required to enhance the activities of the public and private sectors which are doing business with target states for the achievement of security objectives. Even though non-state actors are increasingly important as economic actors, the government is still the largest political and economic actor. This is because it possesses the legal and political authority, as well as the financial resources to promote this type of policy. Thus, the policy-making will of the government is a key factor in the actual instrumentalization of this policy.

Another important actor can be the business community, which is a key possessor and facilitator of cconomic capacity. The will to engage in economic activities in other states by private sectors may mainly be dependent upon expected economic benefits. Thus, it can be imagined that the business environments of target states, and the short and long term profit expectations of the business community are important factors for enhancing business will. The example of the South Korean business community's active involvement with China and the former Soviet Lnion indicates that business interests regarded the two powerful states as potential markets, and this was an important factor in the chaebsls' (South Korean conglomerates) participation in the South Korean government's Nordpolitik, which promored its security objectives. However, as Strange (1996) pointed out, the intentions of the MNCs are not purely profit-related, and may have other motivations. For instance, much longer-term considerations like corporate survival were also important, ${ }^{3}$ Therefore, political decisions, rather than the profit-based strategy of business community, will be investigated, and thus, it is necessary to look at the decision-making factors of the MNCs.

If a state is to perform business-track diplomacy, it needs to possess both economic capability and policy-making will. This article, however, is concerned more with actual policy-making will than business-track diplomacy. The main aim of this study is not to examine whether South Korea possesses the necessary economic capability

\footnotetext{
Strange (1996, 186) quoted Peter Drucker's argument that "[t]he head of a large transnational corporation is a modern Prince, a strategist who must ncgotiate his way through a hostile world... Must compranies have seen an enlargement of their political functions with units devoted to public uffairs and embassies."
} 
for effective business-track diplomacy towards North Korea, but to reveal whether South Korean policy-makers have had the policy-making will to carry out business-track diplomacy towards North Korea as a long-term security policy. By analyzing South Korea's engagement in the Mt. Kumgang tourism project with North Korea, the importance of policy-making will in the utilization of business-track diplomacy will be examined.

\section{ACTORS' POLICY-MAKING WILI OF LALNCHING THE MT. KLIMGANG TOURISM}

The Mt. Kumgang tourism project has provided more than 400,000 South Koreans with the chance to step on North Korean soil. It can be considered a historical event in terms of inter-Korean exchanges and cooperation, as well as and an illustration of what the Kim Dae-Jung government desired to do. The tourism was first negotiated in the North in January 1989, when Chung Ju-Yung, Chairman of the Hyundai Group at that time, signed a memorandum of understanding (MOU) with the North Korean officials. Thus, the Mt. Kumgang tourism took almost ten years to come to fruition.

As mentioned out before, actors' policy-making will, both in the public and the private sectors, is an important factor in implementing business-track diplomacy. The Mt. Kumgang tourism case proved that the involved actors' (the Hyundai Group, the North Korean government, and the Kim Dae-Jung government) inter-Korean business-making will was a crucial factor for the realization of the tourism project. All factors - Hyundai Group founder Chung Ju-Y Yung's tenacity for doing business in North Korean, especially the development of Mt. Kumgang areas, North Korea's willingness to engage economically with South Korean private sectors, and the Kim Dae-Jung government's adoption of the principle of the separation of economics from politics (jenngkyungbunri) in order to enhance private-led economic engagement towards North Kntea, contributed to the success of this tourism.

\section{HYUNDAI GROUP AND CHAIRMAN CHUNG JU-YUNG}

The Mt. Kungang tourism project was possible because of Chung Ju-Yung's will for economic engagement with North Korea. In his memoirs "The Story of My Life, Born in this Country," he pointed out his strong determination to accomplish the Mt. Kumgang development, saying that the "Mt. Kumgang development is our national project and contributes to promoting peace for our nation, moreover, it is my final destiny" (J-Y. Chung 1998, 98), Like other South Korean businessmen whose hometowns were in the North before the Korean War, and who were keen on inter-Korean business, Chung Ju-Yung, who was born in Tongchon, near Mt. 
Kumgang, dedicated the final years of his life to developing business with North Korea, and to helping the North Korean people.

After Kim Dae-Jung government promised strong support for the Mt. Kumgang tourism project, Chung Ju-Yung reportedly said that he was willing to spend 10 percent of his personal capital on the North Korean investment, and directed his sons to open a "North Koraan channel" to re-negotiate the Mt. Kumgang project (M.S. Oh 1998). After several pre-stage talks between Hyundaj Group officials and North Korean officials, Chung Ju-Yung proposed a resumption of talks regarding the Mt. Kumgang tourism project and other businesses, and he announced his desire to donate $1,00 \mathrm{l}$ head of cattle to the North.

Accompanying the first 500 heads of cattle, he visited Pyongyang to discuss inter-Korean economic cooperation with the Asia Pacific Committec (APC) in the North, which is in charge of inter-Korean economic cooperation in North Korea. Returning from the North on 23 June 1998, he announced that the Hyundai Group would launch its first cruise trip to Mt. Kumgang on 25 September 1998. The Hyundai Group chartered two vessels from foreign countries, and started to refurbish Changjun, the nearest port to the mountain in the North. However, North Korea's series of military provocations in the summer of 1998 , which will be discussed later, hindered the deal.

However, both the Hyundai Group and the APC in the North intended to make a deal on the Mr. Kumgang tourism project. Chung Ju-Yung dispatched top executives, including his son Chung Mong-Hun, to Beijing for contacts with North Korean authorities. However, negotiations did not go over smoothly. The Hyundai Group's promised schedules for the first and second take-off of the cruise, in September and October 1998, respectively, were postponed. It was reported that the continuing delay of the tour was caused by a disagteement between the Hyundai Group and North Korea about the price of the tour, and the North Korean military authorities' discontent over opening up Mt. Kumgang and the Changjun Port for the South Korean tour cruisc (Interview with a junior official of the Ministry of Foreign Affairs and Trade (MOFAT), London, Octoher 2000). However, Chung Ju-Yung did not give up on the project. $\mathrm{He}^{2}$ was able to visit North Korea and make his gift of the remaining 501 heads of cartle and 20 sedans made by Hyundai Motors. He finally met the North Korean leader, Kim Jung-Il, on 30 October, extended his stay in the North, and reconfirmed the project with Kim Jung-li.

In fact, the Hyundai Group's cagerness to launch the Mt. Kumgang project was reflected in its generous financial contributions to the North. The basic nature of the Mt. Kumgang deal indicated that the Hyunclai Group will hold exclusive rights to develop the tourist site until the yeat 2030, in return for a total payment of a total US 942 million through March 2005, on a monthly basis. The schedule for the total payment of US\$942 million to the North is to pay a total of US\$ 150 million by June 1999, which is US\$25 million a month for six months, US\$ 72 million over the next nine months, which is US\$8 million a month until March 
of 2000 , and US $\$ 20$ million over the five years through March 2005, which is US\$ 12 million a month (Korea Times, January 5, 1999).

However, industry insiders were hardly optimistic about business prospects unless foreign investors and tourists were attracted to the tour as scon as possible. Also, the business community was not convinced that Mt. Kumgang tourism was a business-oriented project, and it was concerned that the project might pose a burden on other companies seeking to start new businesses with North Korea, especially because of the Hyundai Group's massive financial lobbies and promises to Pyongyang (Korea Times, November 18, 1998).4 Negative views on the profitability of the Mt. Kumgang project also prevailed amongst Hyundai Group officials before the project started.

But, Chung Ju-Yung's strong will to continue the Mt. Kumgang project could not be diminished. His status in the Hyundai Group was such that he was not called "chairman" but "king chairman" by Hyundai Group officials (Shindonga, March 1999). The Mt. Kumgang project was hardly understandable from a business point of view, but it was understandable that a North Korea born businessman would have a strong commitment towards inter-Korean economic cooperation towards the end of his life.

\section{NORTH KOREA'S VULNERABILITY AND BUSINESS WILI.}

Secondly, Mt. Kumgang tourism was possible because the North Korean government had a will to accept South Korean business exchanges, at least from private sectors. As discussed earlier, a target state's economic difficulties and its vulnerability can increase the economic capability of the actors to utilize business-track diplomacy. In fact, North Korea's severe economic difficulties and isolation in the 1990s provided the involved states, including South Korea, with an opporunity to urilize business-track diplomacy towards North Korea.

It was true that the North tried to attract foreign investments from the 1990 s. The tourism industry was already targeted for foreign joint-venture businesses as early as the mid-1980s (Joongangilbo, July 5, 1991). North Korea even designated 1993 as the North Korean tourism year to attract foreigners. However, efforts to attract foreign investment to the tourism industry failed. In fact, Pyongyang asked Japanese conglomerates to develop the Mt. Kumgang area for a tour and resort site, and actually received a basic agreement from some of them. However, these were not realized, primarily because of cheir lack of confidence in the North Korean

\footnotetext{
Most tout operators predicted that considering the tour's high price and the low demand in winter, the Hyundai Group will have to find new customers, such as foreigners. Because the competiriveness of Mc. Kungang rourism was very low, considering that Hyundai chatged around US $\$ 1,000$ for the five-Jay cruise. Hyundai would have to focus on a specific group of local tourists, mostly elderly cirizens who wcre separated from theis fatnilics in the North. However, this would be a shorc-term solution (Kareat Times, November 18, 1998:
} 
government, and the unabated political tension on the Korean Peninsula. To address this situation, the North began to pursue South Korean chaebols, which showed more interest than other foreign corporations in the Mt. Kumgang region.

North Korea's main reasons for pursuing the development of the tourism industry was to acquire hard currency in a short period of time without causing severe damage to its system. For instance, North Korea's toral sum of exports in 1999 was US\$ 637 million, and its net profit might not even exceed Hyundai Group's promised payment of up to an average US\$150 million per year just for the Mt. Kumgang tourism project. Also, North Korea would not need to invest its own money to develop the Mt. Kumgang area. Hyundai's total payment of LS $\$ 942$ million in return for its exclusive right to develop the Mt. Kumgang area through to 2030 could make up for 4 to 5 years of food shortage in North Korea. It is therefore unthinkable that North Kurea would opposc this amazing deal. Thus, the tourist business was too profitable to be denied by North Korea (KOTRA 2001).

In addition to hard currency, the other reason for was to reduce political risk from opening the country to the outside world. For instance, North Korea introduced limited reform and open policies to attract foreign investment in the Rajin-sonbong free trade area in 1991. However, foreign investment brought concerns about the spread of capitalistic ideology through direct contacts between foreign employers and North Korcan employees and citizens. In response to this concern, the North Korean authority omitted the word "free" from the title "Rajin-sonbong free trade zone" in 1999, and deepened the central government's control over the personnct management of foreign firms, the frec trade market at Wonjongni, and commercial advertisements.

Compared with these risks, courism does not require many North Korean employees to manage the business. For example, North Korea committed a minimal number of North Koreans for the Mt. Kumgang tourism business. Currently, people who have direct contact with South Korean tourists are officials of the Immigration Bureau and environmental watchers. Other related pcrsonncl, such as salesmen, nurses, cooks, bus drivers and those un subsidiary facilities, are mostly Korean-Chinese, who are living in northeastern China (Chosunjok). Moreover, citizens around the Mt. Kumgang region, as well as North Korean people of other regions, have only limited access to the tourist sites (K.B. Sub 2001)

This does not mean that launching this project was an easy decision for North Korea. To open the Mt. Kumgang area, a protected military site, and the military port of Changjun. to South Koreans was no easy political decision for Pyongyang, and it should have been regarded as a great change, despite thc Nurth Korean's need for hard currency. For instance, Changjun, a port ciry, nestled at the foor of Mt. Kumgang, has long been North Korea's naval base, accommodating fleets of destroyers and submarines. It was often used for the infiltration of South Korea. The naval base was later relocated eventually to another area because it could no longer maintain its secrecy. Military observers point out that the military importance of the Changiun Port to the North is like that of the Jinhae Port to the South, 
and to open the Jinhac Port to North Koreans for tourism would be impossible, especially considering its strategic importance (Korea Times, November 24, 1998).

Pyongyang's difficulty is evident by the alleged confrontations between military authorities and the APC over the Mt. Kumgang project. For instance, while Chung Ju-Yung reached an agreement with the APC on launching Mt. Kumgang tourism on 23 June 1998, there were two unexpected military infiltrations by North Korea. A North Korean submarine was discovered on the South Korean east coast on 22 June, and an armed North Korean solider was found dead on a South Korean shore in July 1998. These contradictory behaviors by the North, might have reflected the North Korean military authoritics' discontent about Mt. Kumgang tourism, and their effors to hinder the project.

After the two military infiltrations by North Korea, the mood towards the Mt. Kumgang project settled. However, it was the APC, the Narth Korean counterpart of the Hyundai Group for the Mt. Kumgang project, which signaled to the Hyundai Group that it was time to resume talks over the project. This signal led to a series of talks between officials from the Hyundai Group and the APC. However, negotiations between the two were not smooth. Thus, the expected schechule for two take-offs of the Mt. Kumgang trip cruise was postponed. Once again, it was reported that the most important reason for the delay was that Kim Yong-Sun, head of the APC, was having a difficult cime persuading North Korean military authorities. They were reportedly displeased with having no leading role or control over the Mt. Kumgang project, and over the opening of Chang)un Port (Chosunilbo, September 23, 1998).

\section{KIM DAE-JUNG GOVERNMENT'S SUNSHINE POLICY-MAKING}

President Kim Dae-Jung's strong belief in the effectiveness of the sunshine policy and the Kim Dae-Jung government's flexible and consistent economic engagement pusture towards North Korea greatly helped the realization of the Mt. Kumgang toutism project between the Hyundai Group and North Korea. When Kim Dac-Jung trok office, the Hyundai Group resumed its North Korean businesses with small-scale joint projects, such as the import of freight trains made by North Korea in early 1998. In fact, all the Hyundai Group's businesses with the North had been suspended under the Kim Young-Sam government.

Regarding the Mt. Kumgang tourism project, there was full support of the government under the sunshine policy. Before Kim Dae-Jung took office on 28 February 1998, the Undertaking Committee of the Presidential Office of the incoming Kim Dae-Jung government had already selected the Mt. Kumgang project as one of the Kim Dae-Jung government's one hundred tasks for the next five years on 12 February 1998 (Chosunilbo, February 12, 1999). The Kim Dae-Jung government permitted the chairmen of chatbols to visit North Korea without any political preconditions on 1 April 1998. These visits had been banned during the Roh Tae-Woo and Kim Young-Sam governments 
because large-scale investment by South Korean charbols was seen as away to help North Korea's military build-up. ${ }^{5}$ Chung Ju-Yung submitted an application to visit North Korea to the Ministry of Unification the following week.

Following a series of dialogues between the Hyundai Group and North Korea on the Mt. Kumgrang tourism project, Hyundai announced that it had teached a deal with North Korea on 23 June 1998, without asking for South Korean government's permission, which was then still necessary before any public announcement. Instead the Hyundai Group submitted a project application on 1 July 1998 to the Ministry of Unification (MOU). However, there were no legal problems or confrontations between the government and the Hyundai Group. One journalist pointed out that the Hyundai Group's violation of intcr-Korean procedural law would had been a serious political problem during the previous South Korcan governments, because the Hyundai Group' did not observe the principle of "government first and private sector later" on North Korcan affairs, which previous South Korean governments had kept (Interview with a reporter of Shindinga by E-mail, December 11, 1998). Moreover, in the final stage of the tour price negotiation between the Hyundai Group and North Korea, the MOU exempted the group from a series of taxes for the Mt. Kumgang tourism project by revising the Inter-Korean Exchanges and Cooperation Law. It is reported that the Hyundai Group benefited by up to $20 \%$ of the total tour cost from that decision (Cbosunilbo, September 23, 1998).

In fact, compared with the Hyundai Group's difficult relationship with the Kim Young-Sam government, Hyundai Group's Mt. Kumgang tourism project enjoyed cozy relations with the Kim Dae-Jung government. There is no doubt that the Kim Dae-Jung government and the Hyundai Group shared common interests in the success of the Mt. Kumgang project. As far as President Kim Dae-Jung was concerned, since February 1998, when he took office, he put forward his sunshine policy regarding inter-Korean relations, as well as successive calls for government-level dialogue. However, a breakthrough failed to materialize because North Korean provocations continued. In the face of no substantial results from the pledged sunshine policy in the first year of his presidency, Chung Ju-Yung's activities were a very effective way to press ahead with the sunshine policy. In fact, an official of the MOU pointed out that "the Mt. Kumgang tourism is a very important factor in terms of pursuing the sunshine policy. It is the only realistic means to this end and is expected to have a far-reaching effect from a long-term perspective" (Interview with a junior official of MOFAT, Seoul, August 1999).

The Kim Dae-Jung government's support of the Mt. Kumgang project can be seen as a calming response to Pyongyang's concinuing military provocations. When two submarine incidents occurred right after reaching the Mt. Kumgang project deal between the Hyundai Group and North Korea on 23 June 1998, Hyundai's Mt. Kumgang projects narrowly averted cancellation because of a wave of protest from

See Table 1. 
the conservative camp in the South. However, Hyundai's projects have survived all challenges, and suffered only from partial delays, because the Kim Dae-Jung government remained steadfast in their engagement policy toward North Korea. For instance, against the backdrop of the contradictory incidents of Chung Ju-Yung's first visit to North Korea to discuss the Mt. Kumgang tourism project in 17-22 June 1998, and the discovery of a North Korean mini-submarine on 22 June 1998, Seoul announced that its principle of the separation of economics from politics would continue. The Blue House spokesman Park Ji-Won even argued that the "Kim Young-Sam government's handling of North Korea's military provocation, especially the submarine incident in 1996, was rough, and Seoul needed to take a prudent attitude and not provoke Pyongyang" (Chosunilbo, June 23, 1998).

\section{TABle 1. SOUth KOREA's 1998 MEAsures for Revitalisation of INTER-Korean ECONOMIC COOPERATION}

\begin{tabular}{|c|c|c|}
\hline Items & Previous & 19)8 Measure \\
\hline $\begin{array}{l}\text { Level of economic } \\
\text { cooperation }\end{array}$ & $\begin{array}{l}\text { Governmental control of } \\
\text { economic cooperation }\end{array}$ & $\begin{array}{l}\text { Self-regulatory system ander the } \\
\text { responsibility of business entcrprises }\end{array}$ \\
\hline $\begin{array}{l}\text { Visit of North Korea by } \\
\text { Businessmen }\end{array}$ & $\begin{array}{l}\text { Selective permission and the } \\
\text { total ban on chairmen of } \\
\text { chactools }\end{array}$ & $\begin{array}{l}\text { Permit upon preparation of invitation } \\
\text { papers from North Korea }\end{array}$ \\
\hline $\begin{array}{l}\text { The period of visit to North } \\
\text { Korea by businessmen }\end{array}$ & $\begin{array}{l}\text { One year following approval } \\
\text { and single visit only }\end{array}$ & $\begin{array}{l}\text { Three ycars following approval and } \\
\text { multiple visits }\end{array}$ \\
\hline $\begin{array}{l}\text { Period of handling } \\
\text { permission for visit to } \\
\text { North Korea }\end{array}$ & $\begin{array}{l}\text { Contact: 20days } \\
\text { Visit: } 30 \text { days }\end{array}$ & $\begin{array}{l}\text { Contact: } 15 \text { days } \\
\text { Visit: } 20 \text { days }\end{array}$ \\
\hline $\begin{array}{l}\text { Value of production } \\
\text { cquipment allowed to move }\end{array}$ & Less thas US\$ 1 million & No limit \\
\hline $\begin{array}{l}\text { Size of investment in } \\
\text { North Korea per project }\end{array}$ & Maximum IJS\$ 5 million & No limit \\
\hline Investment Items & $\begin{array}{l}\text { Lighir industry and } \\
\text { service sectors }\end{array}$ & $\begin{array}{l}\text { All sectors excluding national defence } \\
\text { and strategic industries }\end{array}$ \\
\hline $\begin{array}{l}\text { Number of items with } \\
\text { trade restriction }\end{array}$ & 205 & $\begin{array}{l}178 \text { and graduit expansion of items } \\
\text { under overall approval }\end{array}$ \\
\hline
\end{tabular}

Source: Quoted from "1998 Measure for Revitalisation of Inter-Korean Economic Cooperation." hrtp:// wurs.unikorea-go.kr/eg/load/c $316 \mathrm{htm}$, published by Ministry of Unification of South Korea.

Morcover, within 20 days of the submarine incident, North Korea's armed infiltrators penetrated into the East coast of South Korean territory. This series of incidents shocked the South Korean people. This time, the South Korean government pushed 
North Korea harder for an apology than in the earlier incident. However, Seoul's engagement policy did not change. Lim Dong-Won, in an interview with the Chosunilto, said that "North Korea's infiltration was a routine operation, and these incidents were evidence that the hard-liners of North Korea wanted to interrupt inter-Korean cooperation. That is why more sunshine is needed to encourage moderate forces in the Nortl" (Chosunilbo, July 13, 1998).

Even with growing criticism from the conservative media for the continuing soft stance towards North Korea's provocations, and an ongoing "suspension campaign of Mt. Kungang tourism" by conservative congressmen from both ruling and opposition parties, the South Korean government continuously leaned towards economic engagement with North Korea. The South Korean government reaffirmed its support for the Mt. Kumgang project based on the principle of separation of economics from politics. The MOL pushed the Mt. Kumgang project by announcing that the process of a Soutb Korean visiting Mt. Kumgang would be simplified through a proxy tour agency, and by allowing a Mt. Kungang development team from the Hyundai Group to frequently visit North Korea, without the government's express permission. President Kim Dae-Jung argued that he would not link the demand for an apology from North Korea for its infiltration to the Mt. Kumgang project. The issue of military security and inter-Korean exchanges go together because inter-Korean economic cooperation would help South Korean security in the long run (Korea Herald, August 14, 1998). In fact, the response from Kim Dac-Jung was quite different to that of former president Kim Young-Sam in 1996, when the first such submarine incident sccurred. President Kim Young-Sam had indicated that an all our war could break out, and suspended all inter-Korean businesses until North Korca apologized for the incident.

The Kin Dae-Jung government also stood up against growing domestic concerns over the possible diversion of North Korean revenue from the Hyundai project to military purposes. According to the MND, North Korea imported military arms valued at US\$ 106 million from Russia and six other countries during 1995-1998 (K-Y. Park 1999, 101). This amount of money could be covered by the Hyundai Group's payment of US $\$ 150$ million in one year alone to North Korca for its exclusive rights over the Mt. Kumgang development for 30 years. In fact, the Hyundai Group is supposed to pay a total amount of US\$ 942 million. However, Kang In-Duk, the Minister of Unification at that time, stepped back and said that "it is up to North Korea what it does with the money because it is a business deal between Hyundai Group and North Korea, and it is not a matter we [the government] should take up" (Korea Times, November 2, 1998). This remark clearly reflected Seoul's incention to distegard these concerns. Beyond the Minister's temark over legal matters relating to North Korea's possible diversion of money into a military build-up, there was the Kim Dae-Jung government's real perception of such concerns.

In Seoul's new understanding of North Korea, it can be argued that North Korea's acquisition of hard currency through the Mt. Kumgang projects did nor increase 
their military threat, even if the money was diverted into military build up. South Korea's military capability still far exceeds that of North Korea. According to SIPRI, for example, South Korea imported arms worth US\$ 5.2 billion, and ranked as fifth in this category in the world from 1994 to 1998 (SIPRJ 1999). South Korea's volume of imported arms was 48 times higher than North Korea's US\$106 million. Furthermore, North Korea's efforts towards military build-up are intended for self-defence rather than the so-called "liberation of the South by force." Considering the changes in the international environment in the 1990s, in which North Korea lost the military support of Russia and China, while fearing continuing potential military threats from the U.S., North Korea's military build-up is understandable. Moreover, South Korea's excessive concern regarding a diversion of money from inter-Korean economic cooperation for military purposes would jcopardize the implementation of an active economic engagement policy towards North Korea (K-Y. Park 1999, 99-102).

It seems that with new beliefs on engagement and new perceptions of the North, the Kim Dae-Jung government's priority in North Korean policy was to help Norrh Korca's constructive transformation towards a market economy. Put differently, the military power of North Korea already holds Seoul hostage with its forward-deployed artillery. Thus, South Koreans should engage North Korea in an attempt to reduce tensions and to support the North's self-reform, because the marginal increase in North Korea's threat capability that might be achieved through economic aid and coopcration is relatively small.

Government support for Mt. Kumgang tourism might also be detected under suspicions and allegations over the Hyundai Group's benefits in domestic business. Compared with Hyundai's disadvantage during the Kim Young-Sam government, the public saw how Hyundai gained political favors from the Kim Dae-Jung government. This is evident in the fact that the Hyundai Group has loomed large in the South Kurcan economy, leaving competing chaebols far behind with a series of take-overs of business divisions under the so-called "big deal" reform program. Initiated by the government, this program involves the swapping of major divisions among the nation's top five chaebols. For example, the merger of the semiconductor divisions between Hyundai Electronics Industries and LG Semicon, valued at US\$ 8 billion in favor of Hyundai, and Hyundai Motor's merger of Kia and Asia Motors, valued at US\$ 6 billion, have consolidated the Hyzndai Group's external status as the No. 1 chaebol of South Korea. Thus, the Hyundai Group is under suspicion of government-business collusion in return for its active business engagement with North Korea (Korea Times, April 21, 1999; August 5, 1999).

\section{CONCLUSION}

This study constructed and employed the concept of "business-track diplomacy" in order to test the theoretical and empirical possibilities of South Korea's utilization 
of economic engagement with North Korea to deal with the inter-Korean security problems. The model explores both the need and the opportunity for South Korea's economic engagement with Nurth Korea, who was usually vicwed as a very hard target for engagement, as well as a country whose security problems have been regarded as military-sriented. Thereby, the business-track diplomacy model presents a perspective that may help policy-makers and scholars to perceive security problems with flexibility and move beyond conventional military perspectives to security.

As seen in the Mt. Kumgang case, this article demonstrated how the decision-makers' policy-making will has contributed to the realization of the Mt. Kumgang project. This is an example of the importance of the strong policy-making will of both the government and the private sector in South Korea to utilize business-track diplomacy towards North Korca. These factors, such as the Hyundai Group founder Chung Ju-Yung's individual will to pursue North Korean business ventures, North Korca's willingness to engage in South Korean business in the face of economic hardship, and the Kim Dae-Jung government's consistent engagement policy towards North Korea all helped to start the $\mathrm{Mt}$. Kumgang tourism project.

\section{REFERENCES}

Baldwin, David. 1985. Economic Statecraft. Princeton, NJ: Princeton University Press. Cho, Dong-Ho. 1996. Nambook Kyunghyu'pui Punggawa Baramjikhan Banghang (Assessment and Desirable Direction of the Inter-Korean Economic Cooperation). Tongilkyungjae (Unification Economy). May: 17-31.

Chung, Ju-Yung. 1998. E Tange Iaeunasu (The Story of My Life, Bom in this Country). Seoul: Sol Press.

Chung, Ok-Nim. 1999. The US-ROK Private Secror Rule in Peace and Security on the Korean Peninsula. The Korean Joumal of Defense Analysis 11 (1): 101-26.

Deutsch, Karl, W. 1957. Political Community and the North Atlanit Area. Princeton, NJ: Princeton University Ptess.

Diamond, Louise and McDonald, John. 1996. Multi-Track Diplomacy: A Systems Approach to Peace. 3rd ed. Connecticut: Kumarian Press.

Friedman, Thomas. 1996. Big Mac I. New York Times, December 8, A3.

Gills, Barry. 1996. Korea Versus Korea: A case of Contested Legitimacy. London and New York: Routledge.

Gleditsch, Nils, Petter, and Hegre, Harvard. 1997. Press and Democracy: Three I.evel of Analysis. Journal of Conflict Resolution 41 (2): 283-310.

Haas, Ernst, B. 1964. Beynd the Nation-State: Functionalist and International Organization. Stanford, CA: Stanford University Press.

Han, Young-Sup. 1998. The Kim Dae-Jung Government's Unification Policy: Will the Sunshine Effect Change in Nurth Korca? Korea and World Affairs 22 (3): 325-40. Hughes, Christopher. 1999. Japan's Economic Prwer and Security: Japan and North Korrea. London: Rourledge.

Hyundai Asan. 2000. Kungangsan Keabal Keebeik: Saupkummia Chujinketheik (Mt.Kumyang 
Detelopment Plan: the Scale of Business and Destopment Plan). http:/www.hyundai-asan. $\mathrm{com} / \mathrm{main}$.asp.

Keohane, Robert and Nye, Joseph. 1977. Power and Interdependence: World Politics in T'ransition. Boston: Little, Brown and Company.

Kim Dae-Jung. 1995. Nauigil Nauisarang (My Way and My Ideology). Seoul: Hangilsa. $\mathrm{Kim}$, Kyu-Ryoon. 2000. Establishment of the South-North Economic Community. International Joumal of Korean Unification Studies 9 (1): 71-96.

Kim, Yong-Ho. 1999. The Kin Young-Sam Government's North Korea Policy and Its Domestic Variants. Intemational Joumal of Krman Inification Studier 8: 225-45.

KOTRA. 2001. Icbunnundo Boolhanui Daeuumuyukdongbang (North Korea's Trade Trend of Y'ear 2000). http://www.kotra.or.kr/main/info/nk/trade/sub06 php3.

Landsberg, Martin. 1998. Korea: Division, Reunification and U.S. Foretgn Policy. New York: Monthly Review Press.

Le, Seong-Bong. 1999. The Political Consequence of the Self-Reliant Economic Development in North Korea. North Korean Studies Review 2 (1): 273-312.

Lim, Dong-Won. 1999. Lim Dong-Won on Sunshine policy: Special Report. http://www nautilus. org/napsnet/sr/index.html.

Montville, Joseph. 1987. The Arrow and the Olive Branch: A Case for Track Two Diplomacy. In Conflict Resolution: Track Two Diplomacy, ed. by John McDonald and Bendahmane. Washington, D.C.: Foreign Service Institutc.

MOU. 1998. 1998 Matasure for Revitalijation of Inter-Korean Fisonomic Conperation. http:// www.unikorea.go.kr/eg/load $/ \mathrm{c} 316 \mathrm{htm}$.

Oberdorfer, Don. 1998. The Two Korkas: A Contempurary History. London: Little, Brown and Company.

Oh, Min-Soo. 1998. Somoli Bangbook Giljapinu Ilbonin Yosida yukda (A Guide of Cattle Diplomacy was Japanese Yosida). Sisa Journal, November 5: 13-14.

Oneal, John, R, and Russett, Burce, M. 1997. The Classical Liberals Were Right: Democracy, Interdependence, and Conflict. 1950-1985. Intermational Studies Quattely 41. (2): $267-94$.

Park, Kun-Young. 1999. Will Mt. Kumgang Tourism Business Contribute to the North Korea's Military Threat? M. Kumgang Tourism Business and inter-Korean Ernomic Cooperation. Seoul: Kyungnam University Press.

Polachek, Solomon William. 1997. Why Democracies Cooperate More and Fight Less: The relationship Between International Trade and Cooperation. Review of Intemational Politics 5 (3): 295-309.

SIPRI. 1999. SIPRI Arms Transfer Database. http:/www.sipri.se/projects/armstrade/atrec93 97.html.

Smith, Hazel. 1999. Opening up by Default: North Korea, the Humanitarian Community and the Crisis. The Pacific Review 12 (3): 453-78.

Srtange, Susan. 1996. The Retreat of the State: The Diffusion of Power in the World Economy. Cambridge, UK: Cambridge University Press.

Suh, Bong-Kyo. 2001. Bookhan Kuankuangtukgu Saupui Sungkongchokun (The Requirement of Successful Mt. Kumgang Special Tourism Zone). Jugankyungjat (Wekly Economy). March 616, Seoul: LG Economic Research Instinte. http:/english.lgeri.co.kr/.

The White House. 1994. A National Secwrity Strategy of Engagement and Enlargement. Washington, D.C.: Times Books (Random House). 